\title{
KINERJA KEUANGAN BANK SEBELUM DAN SELAMA PANDEMI (COVID - 19)
}

\author{
Veronica Stephanie Sullivan dan Sawidji Widoatmodjo \\ Program Studi Manajemen Fakultas Ekonomi dan Bisnis Universitas Tarumanagara, \\ Jakarta
}

Vero.miracle156@gmail.com

\begin{abstract}
This research aims to analyze the financial performance of banks before and during the pandemic (COVID - 19) and to find out what benchmarks are the worst. This analysis uses the CAMEL method, that use ratio such as CAR (Capital Adequacy Ratio), NPL (Non - Performing Loan), ROE (Return on Equity), BOPO (Biaya Operasional terhadap pendapatan operasional), and LDR (Loan to Deposit Ratio). This research uses quantitative method using a comparative approach, because the data used is in the form of numbers and analyzed using statistic, this study is to compare the similarities and differences of 2 or more properties and objects under study in a certain frame of mind. This study uses data from the Financial Report Publication for Quarter II 2019 - III 2020. The study population was taken from banks that have gone public on the IDX (Indonesia Stock Exchange), with a total of 43 banks. The statistical method used is descriptive statistical and paired sample t-test. The result of research from 43 banks show that there are significant differences in CAR, NPL, BOPO on bank performance before and during the pandemic, while ROE and LDR have insignificant differences on bank performance before and during the pandemic.
\end{abstract}

Keyword: Financial Performance, CAMEL, Bank, Pandemic.

Abstrak: Penelitian ini bertujuan untuk menganalisis kinerja keuangan bank sebelum dan selama pandemi (COVID - 19) dan mengetahui tolok ukur apa yang paling buruk. Analisis ini menggunakan metode CAMEL, rasio yang digunakan adalah CAR (Capital Adequacy Ratio), NPL (Non - Performing Loan), ROE (Return on Equity), BOPO (Badan Operasional terhadap Pendapatan Operasional), dan LDR (Loan to Deposit Ratio). Penelitian ini menggunakan metode kuantitatif dengan menggunakan pendekatan komparatif, karena data yang digunakan berupa angka - angka dan menganalisis menggunakan statistika serta penelitian ini bersifat membandingkan persamaan dan perbedaan 2 atau lebih sifat dan objek yang diteliti pada kerangka pemikiran tertentu. Penelitian ini menggunakan data Laporan Keuangan Publikasi Triwulan II 2019 - III 2020. Populasi penelitian diambil dari perbankan yang sudah go public di BEI (Bursa Efek Indonesia), dengan total 43 perbankan. Metode statistik yang digunakan adalah uji statistika deskriptif dan uji t dua sampel dependen. Hasil penelitian dari 43 perbankan menunjukkan bahwa CAR, NPL, BOPO terdapat perbedaan yang signifikan terhadap kinerja bank sebelum dan selama pandemi, sementara ROE dan LDR terdapat perbedaan yang tidak signifikan.terhadap kinerja bank sebelum dan selama pandemi.

Kata Kunci: Kinerja Keuangan, CAMEL, Bank, Pandemi. 


\section{LATAR BELAKANG}

Pada awal tahun 2020 ini, dunia dikejutkan dengan penyebaran virus Covid - 19 yang merupakan pandemi yang meluas ke hamper semua negara, termasuk Indonesia. Corona Virus Deseas 19 (Covid - 19) diputuskan sebagai pandemi oleh World Health Organization (WHO) pada awal tahun 2020. Covid - 19 berdampak ke berbagai jenis sektor, tidak hanya sektor kesehatan, tetapi juga sektor lain, termasuk perbankan. Dampak pandemi Covid 19 pada perbankan adalah pada kinerja perbankan yang nantinya akan mempengaruhi tingkat kesehatan bank. karena itu menjaga kesehatan bank sangat penting. Untuk mengetahui dampak Covid - 19 ini pada kesehatan bank, memerlukan tolok ukur yang obyektif dan tepat. Obyektivitas ini dapat disapai dengan cara membandingkan kesehatan perbankan dalam kondisi lingkungan yang normal, yaitu sebelum terkena pandemi Covid $-19$.

Pasca krisis keuangan tahun 2007 - 2008, manajemen risiko dalam keuangan syariah merupakan topik yang hangat, dan memiliki berbagau eksperimen penelitian yang berbeda dalam faktor internal dan eksternal saat mempengaruhi manajemen risiko (Misman et al., 2015). Kemudian, pada krisis keuangan pada tahun 1997 - 1998, krisis subprime mortgage melanda industry real estate Amerika Serikat. Kemudian krisis ini menyebar ke pasar keuangan global, termasuk negara - negara Asia dan pasar negara berkembang. Kondisi ini merupakan sistem keuangan global yang menurun serta menyusul tekanan yang belum pernah terjadi sebelumnya pada pendanaan dan likuiditas aset. Krisis ini memberikaan banyak dorongan untuk memulai penyelidikan kinerja perbankan, karena hasil penelitian yang dilakukan penting untuk pembuatan kebijakan penilaian kinerja bank yang nantinya mampu menentukan masa depan perbankan.

Dengan menggunakan indikator keuangan yaitu kecukupan modal, kualitas aset, kompetensi manajemen, kualitas laba, dan likuiditas (CAMEL). Kerangka CAMEL dikembangkan oleh bank sentral AS pada awal 1970-an untuk membantu proses struktur pemeriksaan bank. sejak itu, penggunaan faktor CAMEL ini mengevaluasi kesehatan keuangan bank dan menyebar luas dikalangan regulator (Dzeawuni dan Tanko, 2008). Maka dari itu, tolok ukur yang digunakan dapat mengacu pada peraturan yang dikeluarkan oleh Bank Indonesia (BI) No.13/1/PBI/2011, No.6/10/PBI/2004 tanggal 12 April 2004 tentang sistem penilaian tingkat kesehatan bank umum dan surat edaran Bank Indonesia No.6/23/DPNP tanggal 31 Mei 2004 perihal tata cara penelitian tingkat kesehatan pada bank umum (Pandia, 2012:224).

Menurut Heri (2009) mengenai dampak krisis keuangan global terhadap perbankan Indonesia: perbandingan antara bank konvensional dan bank syariah. Dampak bagi perbankan Indonesia dengan adanya penarikan dana oleh investor luar negeri di berbagai perusahaan Indonesia mengakibatkan bank mengalami krisis likuidasi, penurunan nilai aktiva produktif (earning assets) dalam bentuk kredit dan surat berharga yang dibeli bank, penurunan kecukupan modal (CAR) terutama karena kerugian berasal dari pencadangan atas penurunan kecukupan modal aktiva produktif dan gagal bayar bunga kredit. 


\section{KAJIAN TEORI}

\section{Kesehatan Bank}

Teori yang mendasari regulasi di sektor perbankan bersumber dari masalah moral hazard. Paul Krugman (2008) mendefinisikan moral hazard sebagai "setiap situasi di mana seseorang membuat keputusan tentang seberapa besar risiko yang harus diambil, sementara orang lain menanggung biaya jika keadaan memburuk". Masalah ini berasal dari asuransi simpanan yang ada di sebagian besar negara maju. Terdapat konsensus dalam teori ekonomi bahwa asuransi simpanan akan membantu menstabilkan pasar keuangan pada saat krisis dan membantunya menahan guncangan jika terjadi bank run (Nier \& Baumann, 2006). Dalam artikel oleh Diamond \& Dybvig (1983), mereka menunjukkan pentingnya asuransi simpanan dalam arti menenangkan industri bank. Karena bank selalu terkena risiko bank run, diperlukan semacam asuransi. Selama bank run, deposan panik dan mulai menarik simpanan mereka dari bank dengan cepat dan bank mungkin terpaksa melakukan penjualan aset mereka dengan kerugian (Diamond \& Dybvig, 1983).

Untuk mencegah terjadinya hal tersebut di bank, banyak negara yang menerapkan penggunaan asuransi simpanan untuk menenangkan masyarakat bahwa uang mereka aman (Keister, 2016). Tanpa jaminan, deposan asuransi simpanan dapat bergegas ke bank karena takut bank tidak akan dapat membayar kembali semua deposan secara penuh, dan melalui tindakan ini memenuhi kegagalan bank. Dalam artikel berikutnya oleh Diamond dan Dybvig (1986) mereka menyimpulkan bahwa asuransi simpanan adalah satu-satunya tindakan efektif yang diketahui untuk mencegah bank berjalan tanpa mencegahnya menciptakan likuiditas.

\section{Metode CAMEL}

Kerangka CAMELS telah lama digunakan sebagai instrumen pengawasan bank, dan beberapa peneliti menemukan bahwa peringkat CAMELS terkait dengan kinerja dan kesehatan bank secara umum (Chiaramonte, Croci, \& Poli, 2015). Berikut rasio yang digunakan:

\section{a) Permodalan (Capital)}

Dasar permodalan dari setiap lembaga keuangan membantu depositor dalam membentuk presepsi risiko mereka mengenai organisasi. Bank dianggap sebagai pertimbangan yang kuat jika ratio kecukupan modalnya tinggi dan semakin aman dari kebangkrutan. Sesuai dengan norma RBI terbaru terbaru, bank harus memiliki CAR (Capital Adequacy Ratio) 9\% (Kavita, 2019). Dalam melakukan pengukuran terhadap kecukupan modal dapat menggunakan rasio, yaitu:

$$
C A R=\frac{\text { Modal }}{\text { Aktiva Tertimbang Menurut Risiko }} \times 100 \%
$$

b) Kualitas Aktiva (Asset Quality)

Penilaian kualitas aktiva didasarkan kepada kualitas aktiva produktif yang dimiliki bank adalah rasio aktifa produktif yang di klasifikasikan terhadap aktuva produktif (Kasmir, 2012:11). Aset adalah kegiatan pengalokasian dana kedalam berbagai kemungkinan investasi (Pandia, 2012:49). Rasio aset menggambarkan kualitas aktiva dalam perusahaan yang menunjukkan kemampuan dalam menjaga dan mengembalikan 
serta indikator yang digunakan yaitu NPL (Non - Performing Loan). Rasio tersebut dapat dirumuskan sebagai berikut:

$$
N P L=\frac{\text { Total Kredit Bermasalah }}{\text { Total Kredit }} \times 100 \%
$$

c) Manajemen (Management)

Manajemen diperlakukan sebagai salah satu indikator terpenting dalam mendorong kinerja bank, praktik manajemen yang baik dapat menghasilkan keuntungan yang stabil (Teck, 2000). Untuk bisnis per karyawan ini mengukur produktivitas daya manusia pada bank, rasio digunkanan untuk mengukur efisiensi karyawan dalam menghasilkan bisnis bagi bank. ROE (Return on Equity) adalah rasio yang berkaitan pada laba bersih dengan ekuitas pemegang saham, rasio ini untuk menentukkan apakah manajemen mampu memberi nilai tambah bagi pemegang saham (Kavita, 2019). Pengukuran rasio sebagai berikut:

$$
R O E=\frac{\text { Profit }}{\text { Total Equity }} \times 100 \%
$$

d) Rentabilitas (Earnings)

Rentabilitas menggambarkan kemampuan perusahaan untuk mendapatkan laba melalui semua kemampuan dan sumber yang ada, seperti kegiatan penjualan, kas, modal, dan sebagainnya, lalu untuk indikator yang digunakan salah satunya adalah BOPO (Badan Operasional dan Pendapatan Operasional) (Lidya, 2014). Rasio tersebut dapat dirumuskan sebagai berikut:

e) Likuiditas (Liquidity)

$$
\text { BOPO }=\frac{\text { Badan Operasional }}{\text { Pendapatan Operasional }} \times 100 \%
$$

Likuiditas dianggap sebagai salah satu instrumen keuangan yang signifikan dalam melayani hutang keuangan jangka pendek dan memenuhi permintaan pinjaman nasabah, dalam pengelolaan likuiditas dibank yang sehat akan berdampak pada keberhasilan kinerja bank (Dharmenda dan Ahmed, 2016). Rasio likuiditas ini menggambarkan kemampuan bank dalam menyeimbangkan antara likuiditasnya dengan rentabilitasnya (Lidya, 2014), indikator yang digunakan merupakan LDR (Loan to Deposit Ratio). Rasio tersebut dapat dirumuskan sebagai berikut:

$$
L D R=\frac{\text { Total Kredit }}{\text { Dana Pihak Ketiga }} \times 100 \%
$$




\section{Kerangka Pemikiran}

Kerangka pemikiran yang digunakan dalam penelitian ini, sebagai berikut:

\section{PANDEMI}

SEBELUM PANDEMI SESUDAH

\begin{tabular}{|c|c|c|}
\hline Capital & & Capital \\
Asset & & \\
Asset \\
Management \\
Earning \\
Liquidity
\end{tabular}

Berdasarkan kerangka pemikiran diatas, maka muncul hipotesis yang diajukan dalam penelitian, sebagai berikut:

H1: Terdapat perbedaan kinerja bank yang diukur dengan rasio capital antara sebelum dengan sesudah pandemi yang terjadi pada tahun 2020 .

$\mathrm{H} 2$ : Terdapat perbedaan kinerja bank yang diukur dengan rasio assets antara sebelum dengan sesudah pandemi yang terjadi pada tahun 2020 .

H3: Terdapat perbedaan kinerja bank yang diukur dengan rasio management antara sebelum dengan sesudah pandemi yang terjadi pada tahun 2020 .

H4: Terdapat perbedaan kinerja bank yang diukur dengan rasio earning antara sebelum dengan sesudah pandemi yang terjadi pada tahun 2020.

H5: Terdapat perbedaan kinerja bank yang diukur dengan rasio liquidity antara sebelum dengan sesudah pandemi yang terjadi pada tahun 2020 .

\section{METODOLOGI}

Subyek penelitian ini adalah perbankan yang sudah go public di Bursa Efek Indonesia (BEI) pada periode 2019 - 2020. Subyek penelitian ini terdiri dari 43 perbankan. Dalam penelitian ini, terdapat pembatasan terhadap rasio laporan keuangan perusahaan, bertujuan agar mempermudah penelitian dalam mengumpulkan data dari 43 perbankan. Rasio yang diambil merupakan dari laporan keuangan triwulan II dan triwulan III periode 2019-2020. 
Obyek penelitian ini terdiri dari lima variabek dependen yaitu capital, asset, management, earnings, dan liquidity.

Dimana capital diukur dengan Current Adequacy Ratio (CAR), asset diukur dengan Non - Performing Loan (NPL), management diukur dengan Return on Equity (ROE), earnings diukur dengan Badan Operasional terhadap Pendapatan Operasional (BOPO), dan liquidity diukur dengan Loan to Deposit Ratio (LDR). Penelitian ini menggunakan metode kuantitatif dengan pendekatan komparatif, penelitian ini dilakukan untuk membandingkan persamaan dan perbedaan dua atau lebih sifat dan fakta oyek yang diteliti. Instumen penelitian yang digunakan dalam mengumpulkan data melalui dokumentasi, yang diambil melalui dokumen resmi BEI (Bursa Efek Indonesia), OJK (Otoritas Jasa Keuangan), dan situs masing - masing perusahaan. Uji yang digunakan dalam penelitian ini adalah uji $\mathrm{t}$ sampel dependen (paired sample t-test).

\section{HASIL ANALISIS DATA}

\section{Hasil Statistika Deskriptif}

\section{Descriptive Statistics}

Triwulan II 2019

\begin{tabular}{lr|r|r|r|r} 
& & & & & \multicolumn{1}{c}{$\begin{array}{c}\text { Std. } \\
\end{array}$} \\
& N & Minimum & Maximum & Mean & Deviation \\
\hline Capital & 43 & 10,01 & 49,42 & 22,7867 & 8,89592 \\
\hline Assets & 43 &, 62 & 8,60 & 3,4453 & 1,81795 \\
\hline Management & 43 & $-67,00$ & 29,30 & 4,3260 & 14,74653 \\
\hline Earnings & 43 & 60,40 & 146,64 & 90,2986 & 18,51197 \\
\hline Liquidity & 43 & 57,96 & 146,72 & 90,1749 & 17,54720 \\
\hline Valid N & 43 & & & & \\
(listwise) & & & & & \\
\hline
\end{tabular}

\begin{tabular}{lr|r|r|r|r} 
& \multicolumn{5}{c}{$\begin{array}{c}\text { Descriptive Statistics } \\
\text { Triwulan III 2020 }\end{array}$} \\
& N & Minimum & Maximum & Mean & $\begin{array}{c}\text { Std. } \\
\text { Deviation }\end{array}$ \\
\hline Capital & 43 & 10,18 & 133,00 & 27,8044 & 20,22499 \\
\hline Assets & 43 &, 37 & 9,58 & 3,9616 & 2,11391 \\
\hline Management & 43 & $-3087,00$ & 870,00 & $-48,7000$ & 492,57926 \\
\hline Earnings & 43 & 9,76 & 233,91 & 95,4828 & 31,95241 \\
\hline Liquidity & 43 & 54,03 & 157,69 & 88,1451 & 23,84017 \\
\hline Valid N & 43 & & & & \\
(listwise) & & & & & \\
\hline & & & & & \\
\hline
\end{tabular}

\section{Hasil Uji t dua sampel dependen}




\section{Hasil Uji t Dua Sampel Dependen}

(43 Perbankan)

\begin{tabular}{|l|c|c|c|c|}
\hline & $\begin{array}{c}\text { Mean } \\
\text { (Triwulan II } \\
2019)\end{array}$ & $\begin{array}{c}\text { Mean } \\
\text { (Triwulan III } \\
2020)\end{array}$ & Perbedaan & t \\
\hline Capital & 22,79 & 27,08 & $-5,02$ & $-1,68 * *$ \\
\hline Assets & 3,44 & 3,96 & $-0,52$ & $-1,88^{* *}$ \\
\hline Management & 4,33 & $-48,70$ & 53,02 & 0,71 \\
\hline Earnings & 90,30 & 95.48 & $-5,18$ & $-1,58 *$ \\
\hline Liquidity & 90.17 & 88,14 & 2,03 & 0,72 \\
\hline & $* * * *$ Signifikan pada $\alpha \mathbf{0 , 0 1}$ & & \\
& $* * *$ Signifikan pada $\alpha \mathbf{0 , 0 5}$ \\
& $*$ Signifikan pada $\alpha \mathbf{0 , 1}$ & & \\
& $*$ Signifikan pada $\alpha \mathbf{0 , 2}$
\end{tabular}

Berdasarkan hasil uji diatas, dapat dijelaskan, sebagai berikut:

a) Rasio Capital Sebelum dan Selama Pandemi 2020

Nilai rata - rata (mean) triwulan II tahun 2019 dari capital adalah sebesar 22,79 untuk triwulan III tahun 2020 nilai CAR ini adalah sebesar 27,08, berarti rasio modal terhadap aktiva tertimbang menurut risiko (CAR) triwulan II periode 2019 - triwulan III 2020 dari 43 perbankan telah mengalami perbedaan sebesar $-5,02$, yaitu terjadi peningkatan CAR. Semakin tinggi CAR semakin baik, maka telah terjadi perbaikan nilai. Hasil statistika menunjukkan tingkat signifikansi sebesar 0,101 atau tingkat kepercayaan sebesar $90 \%(\alpha$ $0,1)$.

b) Rasio Asset Sebelum dan Selama Pandemi 2020

Nilai rata - rata (mean) triwulan II tahun 2019 dari asset yang diukur dengan NPL adalah sebesar 3,44 sedangkan triwulan III tahun 2020 sebesar 3,96 yang berarti bahwa rasio kredit bermasalah terhadap pinjaman bruto (NPL) triwulan II 2019 - triwulan III 2020 dari 43 perbankan mengalami perbedaan sebesar - 0,52, yaitu terjadi peningkatan NPL. Semakin tinggi NPL menunjukkan semakin tinggi risiko kredit sehingga tidak baik bagi bank. Hasil uji beda variabel aset ini menunjukkan signifikansi sebesar 0,070 dan menggunakan tingkat kepercayaan $90 \%(\alpha 0,1)$.

c) Rasio Management Sebelum dan Selama Pandemi 2020

Nilai rata - rata (mean) triwulan II tahun 2019 dari management adalah sebesar 4,33 sedangkan triwulan III tahun 2020 sebesar $-48,70$ yang berarti bahwa laba bersih terhadap total ekuitas (ROE) triwulan II 2019 - triwulan III 2020 dari 43 perbankan telah mengalami perbedaan yang drastic sebesar 53,02, yaitu terjadi penurunan ROE. Berarti nilai ROE triwulan III lebih kecil dari nilai ROE triwulan II. Hasil signifikansi menunjukkan sebesar 0,483 yang dimana hal ini menunjukkan jauh dari tingkat kepercayaan yang biasa digunakan. 
d) Rasio Earning Sebelum dan Selama Pandemi 2020

Nilai rata - rata (mean) triwulan II tahun 2019 dari earning adalah sebesar 90,30 sedangkan trriwulan III tahun 2020 sebesar 95,48 yang berarti bahwa rasio beban operasional terhadap pendapatan operasional (BOPO) triwulan II periode 2019 - triwuln III 2020 dari 43 perbankan telah mengalami perbedaan sebesar $-5,18$, yaitu terjadi peningkatan BOPO. Semakin tinggi BOPO berarti semakin tidak eefisien biaya operasional yang dikeluarkan oleh bank, sehingga kondisi bermasalah bank semakin besar. Hal ini ditunjukkan dari angka perbedaan yang negatif. Hasil uji beda menunjukkan tingkat signifikansi sebesar 0,121 dengan melonggarkan kepercayaan hingga $80 \%$ atau $\alpha 0,2$.

e) Rasio Liquidity Sebelum dan Selama Pandemi 2020

Nilai rata - rata (mean) triwulan II tahun 2019 dari liquidity adalah sebesar 90,17 sedangkan triwulan III tahun 2020 sebesar 88,14 yang berarti bahwa total pinjaman terhadap rasio deposit (LDR) triwulan /ii periode 2019 - triwulan III 2020 dari 43 perbankan mengalami perbedaan sebesar 2,03, yaitu terjadi penurunan LDR. Berarti nilai LDR triwulan III lebih kecil dari nilai LDR triwulan II, semakin rendah LDR semakin baik. Uji t menunjukkan bahwa tingkat signifikansi sebesar 0,474 yang dimana hasil ini tentu jauh dari tingkat kepercayaan yang biasa digunakan di ilmu sosial.

\section{DISKUSI}

Berdasarkan hasil pengujian diatas, dapat disimpulkan, sebagai berikut:

Pada hasil pengujian H1 menunjukkan bahwa terdapat perbedaan yang signifikan terhadap kinerja bank, yang diukur dengan CAR antara sebelum dan selama pandemi (Ho ditolak, $\mathrm{H} 1$ diterima). Hasil pengujian $\mathrm{H} 2$ menunjukkan bahwa terdapat perbedaan yang signifikan terhaadap kinerja bank, yang diukur dengan NPL antara sebelum dan selama pandemi (Ho ditolak, H2 diterima). Hasil pengujian H3 menunjukkan bahwa terdapat perbedaan yang tidak signifikan terhadap kinerja bank, yang diukur dengan ROE antara sebelum dan selama pandemi (Ho diterima, H3 ditolak). Hasil pengujian H4 menunjukkan bahwa terdapat perbedaan yang signifikan terhadap kinerja bank, yang diukur dengan BOPO antara sebelum dan selama pandemi (Ho ditolak, H4 diterima), tentu hipotesis keempat ini tidak diterima jika menggunakan tingkat kepercayaan yang tinggi. Dan Hasil pengujian H5 menunjukkan bahwa terdapat perbedaan yang tidak signifikan terhadap kinerja bank, yang diukur dengan LDR antara sebelum dan selama pandemi (Ho diterima, H5 ditolak).

Sehingga hal ini membuktikan bahwa beberapa penelitian terdahulu, yaitu: Beni (2008) mengatakan bahwa dari sisi asset, management, maupun earnings menunjukkan perbedaan yang tidak signifikan antara kinerja sebelum krisis ekonomi dengan kinerja pada masa krisis ekonomi, sedangkan capital dan liquidity terjadi penurunan yang signifikan. Surifah (2002) mengatakan bahwa rasio capital, asset, management, dan liquidity berbeda secara signifikan antara sebelum dan setelah krisis, namun aspek earning tidak berbeda secara signifikan. Lalu Suci (2012) mengatakan bahwa tidak ada perbedaan yang signifikan antara kinerja CAMELS. Salhuteru dan Wattimena (2015) mengatakan bahwa CAR tidak memiliki pengaruh yang substansial dan LDR berpengaruh positif tetapi tidak signifikan.

\section{PENUTUP}

Berdasarkan hasil uji beda dan pembahasan yang sudah dilakukan secara keseluruhan dapat disimpulkan bahwa secara umum perbedaan kinerja bank antara sebelum pandemic 
COVID - 19, yang ditunjukkan CAMEL triwulan II 2019, dengan selama pandemi, yang ditunjukkan CAMEL triwulan III 2020, tidak signifikan jika menggunakan tingkat kepercayaan tinggi $\alpha 0,05$. Namun jika tingkat kepercayaan itu diturunkan menjadi $\alpha 0,1$ maka ada beberapa indikator CAMEL yang signifikan. Dengan hasil seperti itu dapat dikatakan bahwa dampak pandemi COVID - 19 belum dapat dirasakan oleh industri perbankan.

Saran yang dapat diberikan oleh peneliti adalah meskipun secara umum belum ada dampak yang signifikan atas industri perbankan, para pengelola perbankan harus berhatihati, karena jika tingkat kepercayaan diturunkan, dampak tersebut dapat segera terjadi. Untuk periode yang digunakan disarankan dapat menggunakan periode yang lebih jauh lagi, hasil CAMEL yang signifikan disarankan untuk menjaga rasio tersebut. Bagi penelitian mendatang akan lebih baik jika dapat meneliti kinerja keuangan sektor lainnya dan tidak hanya sektor perbankan sehingga wawasan mengenai kinerja keuangan sebelum dan selama pandemi dapat lebih luas dipahami, mempersiapkan metode penelitian kinerja keuangan lainnya dan tidak hanya menggunakan metode CAMEL, dan untuk rasio keuangan yang digunakan sebaiknya diperluas penggunaan rasio keuangannya agar dapat memperluas dan melengkapi pengetahuan dari penelitian sebelumnya.

\section{DAFTAR PUSTAKA}

Amelia, E., Astiti, D., \& Aprilianti, C. (2018). PENILAIAN TINGKAT KESEHATAN BANK: PENDEKATAN CAMEL DAN RGEC (Studi Pada Bank Maybank Syariah Indonesia Periode 2011-2016). Jurnal Akuntansi Dan Keuangan Islam, 6(2), 189 207.

Aspal, P. K., \& Dhawan, S. (2014). Financial performance assessment of banking sector in India: A case study of old private sector banks. The Business \& Management Review International Trade \& Academic Research Conference, 5(3), 3-4.

Braja, D. (2012). ANALISIS PENGARUH RASIO CAMELS TERHADAP PREDIKSI KONDISI BERMASALAH PADA BANK UMUM YANG TERDAFTAR DI BURSA EFEK INDONESIA PERIODE 2007-2012. 66, 37-39.

Chiaramonte, L., \& Casu, B. (2017). Capital and liquidity ratios and financial distress. Evidence from the European banking industry. The British Accounting Review , 49, 138-161.

Dahiyat, A. (2012). The Application of CAMELS rating system to Jordanian brokerage firms. International Research Journal of Finance and Economics, 88(April 2012), $16-23$.

Diamond, D., \& Dybvig, P. (1983, June). Bank Runs, Deposit Insurance, and Liquidity. Journal of Political Economy, 91(3), 401-419.

Diamond, D., \& Dybvig, P. (1986, January). Banking Theory, Deposit Insurance, and Bank Regulation. Th eJournal of Business, 59(1), 55-68.

Faisal, A., Samben, R., \& Pattisahusiwa, S. (2018). Analisis kinerja keuangan. Kinerja, 14(1), 6. https://doi.org/10.29264/jkin.v14i1.2444

Fatmala, E., Hakim, D. B., \& Anggraeni, L. (2019). Efisiensi dan Produktivitas Perbankan Sebelum dan Setelah Krisis Keuangan. Jurnal Aplikasi Bisnis Dan Manajemen, 5(2), 200-209. https://doi.org/10.17358/jabm.5.2.200

Ghasempour, S., \& Salami, M. (2016). Ranking Iranian Private Banks Based on the CAMELS Model Using the AHP Hybrid Approach and TOPSIS. International Journal of Academic Research in Accounting, 6(4), 52-62. https://doi.org/10.6007/IJARAFMS/v6-i4/2294 
Hafidhin, R., Rahayu, S. M., \& ZA, Z. (2018). Analisis Tingkat Kesehatan Bank Dengan Menggunakan Metode Risk Profile , Earnings And Capital (Studi Pada PT. Bank Mandiri (Persero) Tbk. Periode 2013-2016). Jurnal Administrasi Bisnis, 57(2), 116125.

Kevin, J., Jacob, D., Ekonomi, F., Akuntansi, J., Sam, U., \& Manado, R. (2011). bank, CAMEL, kesehatan bank. 1(3), 691-700.

Krugman, P. (1999, 2008). The Return of Depression Economics and The Crisis of 2008. London: $\quad$ Penguin Books

Ledhem, M. A., \& Mekidiche, M. (2020). Economic growth and financial performance of Islamic banks: a CAMELS approach. Islamic Economic Studies. https://doi.org/10.1108/IES-05-2020-0016

Masood, O., Ghauri, S. M. K., \& Aktan, B. (2016). Predicting Islamic banks performance through CAMELS rating model. Banks and Bank Systems, 11(3), 37-43. https://doi.org/10.21511/bbs.11(3).2016.04

Muhmad, S. N., \& Hashim, H. A. (2015). Using the Camel Framework in Assessing Bank Performance in Malaysia. International Journal of Economics, Management and Accounting, 23(1), 109-127.

Nier, E., \& Baumann, U. (2006). Market discipline, disclosure and moral hazard in banking. Journal of Financial Intermediation (15), 332-361.

Paputungan, D. F. (2016). Penilaian Tingkat Kesehatan Bank Menggunakan Metode CAMEL Pada PT. Bank Rakyat Indonesia Cabang Manado Periode 2010-2015. Jurnal EMBA: Jurnal Riset Ekonomi, Manajemen, Bisnis Dan Akuntansi, 4(3), 729_ 740.

Purba, H. Y. (2015). ANALISIS CAMEL UNTUK MENILAI PERFORMANCE PERUSAHAAN PERBANKAN (Studi pada Bank-bank Milik Pemerintah yang Go Public di BEI). Jurnal Administrasi Bisnis (JAB), 29(1), 86-94.

Singh, D., \& Al-Balushi, A. A. R. (2016). Performance Measurement of GCC Banks: A CAMEL Approach. Globsyn Management Journal, 10(1/2), 56-65.

Sugema, I. (2012). Krisis Keuangan Global 2008-2009 dan Implikasinya pada Perekonomian Indonesia (2008-2009 th Global Financial Crisis and Its Implications on Indonesian Economy). Jurnal Ilmu Pertanian Indonesia (JIPI), 17(3), 145-152.

Syahputra, R. (2018). Analisis Tingkat Kesehatan Bank Dengan Metode CAMEL Pada PT. Bank Artos Indonesia Tbk, Periode 2014-2017. JURNAL AKUNTANSI DAN BISNIS : Jurnal Program Studi Akuntansi, 4(1). https://doi.org/10.31289/jab.v4i1.1546

Vadrale, K. S. (2019). Financial Performance of Selected Public and Private Sector Banks in the Light of CAMEL Model. ... : International Journal of Money, Banking \& ..., $8($ June), 49-59.

Wahyudi, R. (2020). Analisis Pengaruh CAR, NPF, FDR, BOPO dan Inflasi terhadap Profitabilitas Perbankan Syariah di Indonesia: Studi Masa Pandemi Covid-19. AtTaqaddum, 12(1), 13. https://doi.org/10.21580/at.v12i1.6093

Yulianto, A. (2011). Analisis CAMELS dalam Memprediksi Tingkat Kesehatan Bank yang Terdaftar di Bursa Efek IndonesiaPeriode Tahun 2009-2011 Agung Yulianto, Wiwit Apit Sulistyowati. 35-49. 